\title{
Развитие рынка дворянских землевладений и его влияние на перераспределение частной земельной собственности в Центральном Черноземье в 1860-1890-е годы
}

\author{
В.А. Тонких ${ }^{1}$, В.В. Громова ${ }^{2}$ \\ ${ }^{1}$ Воронежский государственный университет, \\ Россия, 394018, г. Воронеж, Университетская площадь, 1 \\ ${ }^{2}$ Белгородский государственный национальный исследовательский университет, \\ Россия, 308015, г. Белгород, ул. Победы, 85 \\ E-mail: Gromvv@mail.ru
}

\begin{abstract}
Аннотация. С отменой крепостного права постепенно стали сниматься сословные ограничения для свободного перехода земли от дворян в собственность других сословий. Появились предпосылки для развития межсословного земельного рынка. В то же время во второй половине XIX века представители дворянского сословия продолжали оставаться основными участниками земельного рынка. В статье рассматривается эволюция торговых отношений дворянского сословия на земельном рынке Центрального Черноземья в 1860-1890-е годы. На основе анализа материалов по статистике движения землевладения в 45 губерниях Европейской России выявлены тенденции, происходившие на земельном рынке с 1863 по 1892 год. Изменения купли-продажи дворянских землевладений в Центральном Черноземье сопоставлены с общероссийскими данными, выявлены сходные и отличительные черты. Поскольку развитие земельного рынка оказывало существенное влияние на межсословное перераспределение частной земельной собственности, в статье рассмотрено изменение структуры землевладения в Центральном Черноземье в 1877 и 1905 годах. Определены основные сословия частных земельных собственников, выявлено их количество и размеры их землевладений. Отдельно рассмотрена структура частного землевладения Курской губернии, которая из всех губерний Центрального Черноземья отличалась наибольшим количеством мелких земельных собственников.
\end{abstract}

Ключевые слова: земельный рынок, дворяне, продавец, покупатель, сделка, покупка, продажа, десятина, товарооборот.

Для цитирования: Тонких В.А., Громова В.В. 2021. Развитие рынка дворянских землевладений и его влияние на перераспределение частной земельной собственности в Центральном Черноземье в 1860-1890-е годы. Via in tempore. История. Политология, 48 (1): 150-158 (in Russian). DOI: $10.52575 / 2687-0967-2021-48-1-150-158$.

\section{The noble land market development and its impact on the land property redistribution in the central Chernozem region from the 1860 's to the 1890's}

\author{
Vladimir A. Tonkikh ${ }^{1}$, Viktoriya V. Gromova ${ }^{2}$ \\ ${ }^{1}$ Voronezh State University, \\ 1 Universitetskaya Square, Voronezh, 394018, Russia \\ ${ }^{2}$ Belgorod State University, 85 Pobeda St., Belgorod, 308015, Russia \\ E-mail: Gromvv@mail.ru
}

Abstract. With the serfdom era gone, estate ownership restrictions had been eliminated by and by. Some
possibilities for the inter-caste land market development had come about. Meanwhile, during the second
half of the 19th century the nobles had been remaining major participants of the land trading. The article 
is dedicated to the evolution of trading relations among the nobles in the land market of the Central Chernozem Region from the 1860's to the 1890's. Due to the land trading statistics analysis, land market tendencies from 1863 to 1892 were identified in 45 regions of the European Russia. Modifications of purchase and sale of the noble lands in the Central Chernozem Region were compared with the allRussian ones; similar and different features were detected. As the land market development had a great impact on the inter-caste private property redistribution, modifications of the land ownership formation in the Central Chernozem Region in 1877 and 1905 are mentioned in the article. The main estates of land owners were identified, quantity and sizes of their land properties were determined. The land tenure formation of the Kursk Region possessing the biggest number of smallholders was individually considered.

Keywords: land market, nobility, seller, customer, transaction, purchase, sale, tithe, trade.

For citation: Tonkikh V.A., Gromova V.V. 2021. The noble land market development and its impact on the land property redistribution in the central Chernozem region from the 1860's to the 1890's. Via in tempore. History and political science, 48 (1): 150-158. DOI: 10.52575/2687-0967-2021-48-1-150-158.

Земля в качестве товара является одним из основных компонентов аграрного рынка, от степени развития которого в XIX веке зависело национальное благосостояние России. Условия для зарождения и развития земельного рынка возникли с началом проведения реформ по отмене крепостного права, так как постепенно стали сниматься сословные ограничения для свободного перехода земли от дворян в собственность других сословий.

С 1863 по 1892 годы в 45 губерниях Европейской России было совершено 565788 сделок по продаже земли и соответствующее количество сделок по ее покупке. Товарооборот земельного рынка составил 80727 тыс. дес. стоимостью 2027 млн руб. На долю дворянского сословия пришлось 45 \% сделок по продаже земли и 17 \% сделок по ее покупке, 71 \% проданной и $41 \%$ купленной земли. От продажи земли дворяне получили 1459 млн руб. или 72 \% капиталов земельного рынка. На покупку земли дворяне затратили 821 тыс. руб., что составляло 56 \% от суммы, полученной в результате ее продажи. По всем приведенным показателям дворяне больше других сословий были вовлечены в торговые отношения на земельном рынке. И только по количеству сделок-покупок они были на втором месте после крестьян, на долю которых приходилось $44 \%$ всех сделок-покупок [Материалы по статистике..., 1901, с. 2-13].

В Центрально-Черноземном районе, включающем 10 губерний (Воронежскую, Курскую, Орловскую, Тамбовскую, Тульскую, Рязанскую, Казанскую, Пензенскую, Саратовскую, Симбирскую), было совершено 30 \% сделок по продаже земли и $23 \%$ сделок по ее покупке, продано 15 \% земли и обращалось 28 \% капиталов земельного рынка России. Дворяне района совершили 56954 сделки по продаже земли и 25455 сделок по ее покупке, продали 9163 тыс. дес., купили - 5900 дес. От продажи земли они выручили 425 млн руб., на покупку земли затратили 262 млн руб. [Материалы по статистике..., 1901, с. 50-61].

Степень вовлеченности дворянского сословия в торговые отношения на земельном рынке района в основном соответствовала общероссийским показателям. При этом товарооборот дворянских землевладений был немного больше, чем в среднем по Европейской России. На долю дворян приходилось 78 \% проданной и 50 \% купленной в районе земли [Материалы по статистике..., 1901, с. 50-61].

В указанный период в Европейской России дворяне в 2,7 раза чаще продавали землю, чем покупали. В Центральном Черноземье этот показатель был немного меньше - количество дворянских сделок по продаже земли в 2,2 раза превышало количество сделок по покупке [Материалы по статистике..., 1901, с. 2-9, 50-57].

В 1860-1890-х годах купля-продажа дворянских землевладений изменялась циклически. Количество дворянских сделок по продаже земли изменялось синхронно с количеством сделок по ее покупке. 


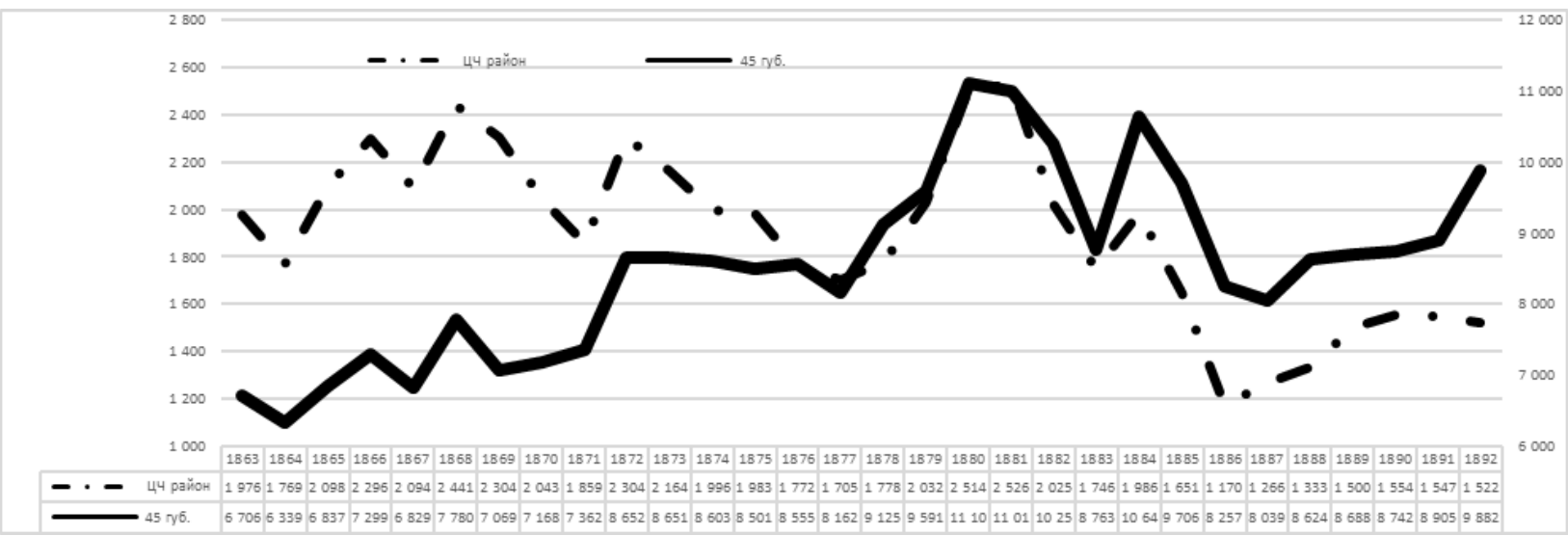

Рис. 1. Количество сделок по продаже земли, совершенных дворянами за период с 1863 по 1892 год [Материалы по статистике..., 1901, с. 2-3, 56-57]

Fig. 1. Number of land transactions committed by nobles during the period from 1863 to 1892

С 1863 по 1880 год продажа дворянских землевладений в Европейской России нарастала. В Центрально-Черноземном районе продажа дворянских землевладений была подвержена более частым изменениям, чем в целом по России. В 1863 году дворяне района совершили 1976 сделок по продаже земли. С 1863 по 1868 годы количество сделок выросло в 1,2 раза до 2441 сделки. С 1869 года начала прослеживаться тенденция к спаду продаж, который в целом продолжался в течение 9 лет до 1877 года. За этот период количество дворянских сделок по продаже земли относительно 1868 года сократилось в 1,4 раза. Начиная с 1878 года изменения на земельном рынке Центрально-Черноземного района стали соответствовать и общероссийским тенденциям - купля-продажа дворянских землевладений начала увеличиваться. В 1881 году было совершено в 1,5 раза больше сделок по продаже земли, чем в 1877 году [Материалы по статистике..., 1901, с. 56-57].

В 1879-1881 годах в Центрально-Черноземном районе и в целом по всей Европейской России купля-продажа дворянских землевладений достигла пика. В 1880 году в 45 губерниях Европейской России дворяне совершили 11107 сделок по продаже земли и 3792 по ее покупке, в Центрально-Черноземном районе - 2514 и 1039 сделок соответственно. В Европейской России по сравнению с 1863 годом продажа дворянских землевладений выросла в 1,6 раза, покупка - в 1,17 раза. В Центральном Черноземье рост купли-продажи был менее существенным - продажа выросла в 1,3 раза, а покупка практически не изменилась - ее рост составил всего 6\%. С 1882 по 1886 год на земельном рынке наблюдался спад, при этом в 1884 году купля-продажа дворянских землевладений повсеместно выросла, а в 1885 году спад продолжился. В 1886 году в Центрально-Черноземном районе купля-продажа дворянских землевладений достигла минимальных значений за тридцатилетний период с 1863 по 1892 год. В 1886 году дворяне совершили 1170 сделок по продаже земли и 559 сделок по ее покупке, что соответственно в 2,4 и 1,9 раза меньше, чем в 1880 году. В Европейской России в целом спад купли-продажи был менее резким, чем в Центрально-Черноземном районе - количество дворянских сделок по покупке и по продаже сократилось в 1,3 раза каждая. С 1887 по 1892 год на земельном рынке вновь начался подъем [Материалы по статистике..., 1901, с. 56-57].

Таким образом, в течение рассматриваемого периода с 1863 по 1892 год в Европейской России и, в частности, в Центрально-Черноземном районе дворяне были основным участником земельного рынка. Начиная с 1878 года изменения, происходившие на земельном рынке Центрального Черноземья, соответствовали общероссийским тенденциям.

В течение рассматриваемого тридцатилетнего периода с 1863 по 1892 год в Европейской России в среднем в год продавалось 1918 тыс. дес., покупалось 1110 тыс. дес., 
в Центральном Черноземье - 305 тыс. дес. и 197 тыс. дес. соответственно. В ЦентральноЧерноземном районе покупали земли на 30 \% меньше, чем продавали.

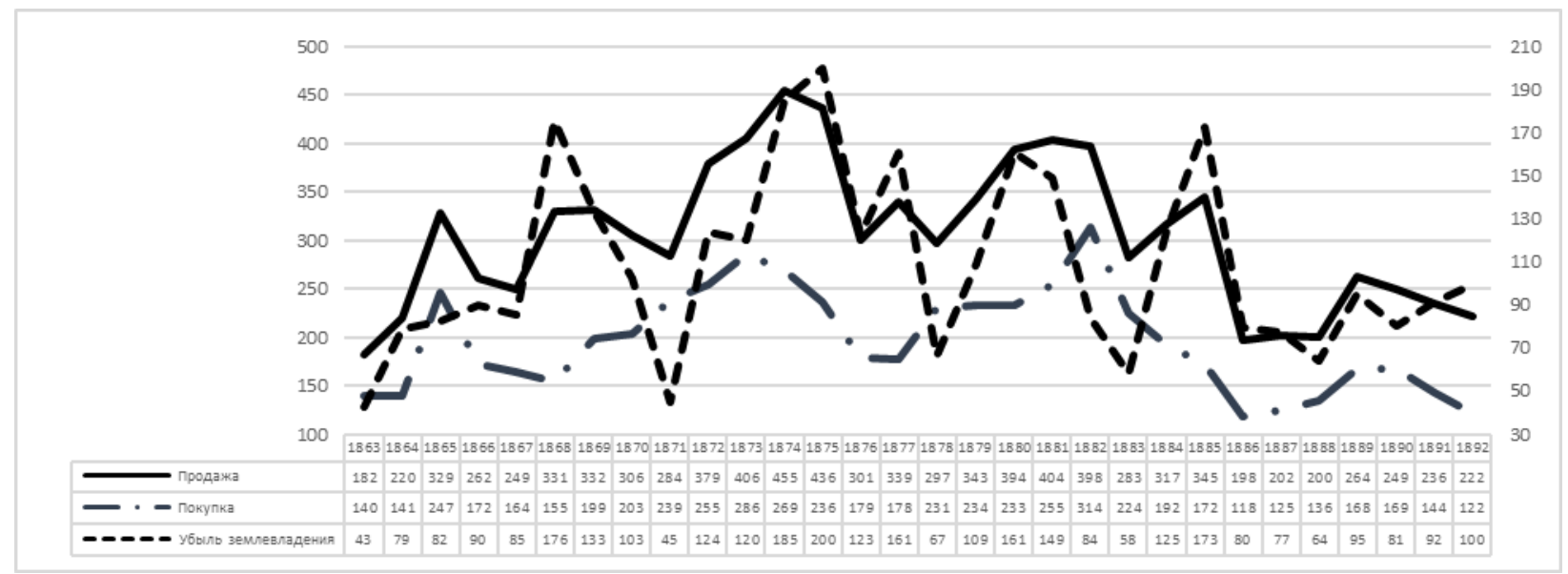

Рис. 2. Количество десятин, проданных и купленных дворянами Центрально-Черноземного района с 1863 по 1892 год [Материалы по статистике..., 1901, с. 58-59]

Fig. 2. Number of dessiatinas bought and saled by nobles in The Central Chernozem Region from 1863 to 1892

С 1863 по 1874 годы количество проданной и купленной дворянами земли постепенно увеличивалась.

Несмотря на то, что в 1869-1877 годах количество дворянских сделок по куплепродаже земли сокращалось, это не повлияло на количество проданной и купленной земли. В 1874-1875 годах дворянами района было продано максимальное за тридцатилетний период количество земли - 455 и 436 тыс. дес. соответственно. Несмотря на то, что в эти годы дворяне не только много продавали земли, но и покупали, в районе наблюдалась самая большая убыль дворянского землевладения за весь тридцатилетний период. Сокращение количества сделок и увеличение количества проданной и купленной земли свидетельствуют о совершении дворянами крупных сделок по купле-продаже земли. В эти годы на одну сделку приходилось 228 и 220 дес. земли, что было значительно выше среднего (162 дес.) [Материалы по статистике..., 1901, с. 58-59].

Второй по величине пик купли-продажи дворянских землевладений был в 1880-1882 годах. В эти годы дворяне совершили максимальное количество сделок по купле-продаже земли, продано 394, 404 и 398 тыс. дес., куплено 286, 269, и 314 тыс. дес. соответственно. На одну сделку в среднем приходилось по 160 дес., т. е. земля продавалась и покупалась более мелкими партиями, чем в 1874-1875 годах [Материалы по статистике..., 1901, с. 58-59].

Начиная с 1883 года стала прослеживаться тенденция к сокращению количества проданной и купленной дворянами земли. В 1886 году по сравнению с 1882 годом продажа дворянских землевладений сократилась на 51 \%, покупка - на 62 \%. Несмотря на то, что с 1887 года количество дворянских сделок по купле-продаже земли начало увеличиваться, площадь проданных и купленных земель сокращалась до 1892 года. С 1886 по 1892 год дворяне продавали и покупали меньше земли, чем в предыдущие 17 лет. Количество ежегодно продаваемых десятин колебалось от 198 тыс. дес. до 264 тыс. дес., купленных - от 118 тыс. дес. до 169 тыс. дес. [Материалы по статистике..., 1901, с. 58-59].

С 1863 по 1892 гг. дворяне продали земли в 1,55 раза больше, чем купили. В результате совершенных сделок дворяне потеряли 3263 тыс. дес. Указанное количество земли перешло к другим сословиям [Материалы по статистике..., 1901, с. 52-53, 58-59]. 
К 1877 году в частной собственности района находилось 15,6 млн дес., что составляло $32 \%$ от общей площади района (49 млн дес.) [Островский, 2013, с. 25] и 16,7 \% от частновладельческих земель 49 губерний Европейской России (93,9 млн дес.). Из этого количества на долю личных земельных собственников пришлось 15,3 млн дес. Собственность обществ и товариществ была незначительной -242 тыс. дес. $-1,5 \%$ от частной земельной собственности района [Статистика землевладения..., 1907. С. 12-17].

Таблица 1

Table 1

Структура частных землевладений в Центрально-Черноземном районе в 1877 и 1905 годах

[Статистика землевладения..., 1907, с. 12-17].

Private landownership formation in The Chernozem Region in 1877 and 1905

\begin{tabular}{|l|c|c|c|c|c|c|}
\hline \multirow{2}{*}{ Сословия } & \multicolumn{3}{|c|}{1877 год } & \multicolumn{3}{c|}{1905 год } \\
\cline { 2 - 7 } & $\begin{array}{c}\text { Кол-во } \\
\text { собствен } \\
\text {-ников }\end{array}$ & $\begin{array}{c}\text { Кол-во } \\
\text { земли } \\
\text { (тыс. } \\
\text { дес). }\end{array}$ & $\begin{array}{c}\text { Средний } \\
\text { размер } \\
\text { землевладения }\end{array}$ & $\begin{array}{c}\text { Кол-во } \\
\text { собствен } \\
\text {-ников }\end{array}$ & $\begin{array}{c}\text { Кол-во } \\
\text { земли } \\
\text { (тыс. } \\
\text { дес). }\end{array}$ & $\begin{array}{c}\text { Средний } \\
\text { размер } \\
\text { землевладени } \\
\text { я }\end{array}$ \\
\hline Дворяне & 26830 & 12550 & 468 & 21334 & 8484 & 398 \\
\hline Купцы & 3665 & 1695 & 462 & 5347 & 1959 & 366 \\
\hline Мещане & 6446 & 226 & 35 & 8474 & 503 & 59 \\
\hline Крестьяне & 57318 & 793 & 14 & 81628 & 1758 & 22 \\
\hline Иностранные подданные & 50 & 15 & 306 & 75 & 40 & 535 \\
\hline Прочие сословия & 1358 & 54 & 40 & 3950 & 267 & 68 \\
\hline Итого & 95667 & 15333 & - & 120808 & 13011 & - \\
\hline $\begin{array}{l}\text { Частная собственность } \\
\text { обществ и товариществ }\end{array}$ & & 242 & & & 2129 & \\
\hline Всего & & 15575 & & & 15140 & \\
\hline
\end{tabular}

В общем фонде личного землевладения района (15,3 млн дес.) - дворянам принадлежало $82 \%$, купцам ${ }^{32}-11 \%$, крестьянам $-5,2 \%$, мещанам $-1,5 \%$, прочим сословиям менее $1 \%$ [Статистика землевладения..., 1907, с. 16].

В 1877 году общее количество личных земельных собственников района составляло 95667 человек. Большинство (60\%) собственников были крестьяне. На одного владельца крестьянского сословия в среднем приходилось 14 дес. Мещане составляли $7 \%$ личных земельных собственников, а средний размер их землевладений был в два раза больше, чем у крестьян - 35 дес. Дворяне и купцы составляли 28 \% и 4 \% личных землевладельцев. На одного владельца этих сословий в среднем пришлось 468 дес. и 462 дес. соответственно [Статистика землевладения..., 1907, с. 16].

К 1905 году в районе в частной собственности находилось 15,1 млн дес., из них личным владельцам принадлежало 13 млн дес. или 86 \%, обществам и товариществам 2,1 млн дес. или 14 \%. По сравнению с 1877 годом земельная собственность обществ и товариществ увеличилась практически в 9 раз [Статистика землевладения..., 1907, с. 15].

В общем фонде личного землевладения на долю дворян приходилось $65 \%$, купцов $-15 \%$, крестьян $-14 \%$, мещан $-4 \%$, прочих сословий $-2 \%$.

Количество личных земельных собственников выросло в 1,3 раза до 120808 человек. Из этого количества крестьяне составляли $68 \%$, дворяне - $18 \%$, купцы - $15 \%$, мещане - 14 \%. На одного землевладельца дворянского сословия пришлось 398 дес., купеческого - 366 дес., крестьянского - 22 дес., мещанского - 59 дес. земли [Статистика землевладения..., 1907, с. 12-13.]

\footnotetext{
32 Вместе с почетными гражданами.
} 
Таким образом, к 1905 году по сравнению с 1877 годом количество земельных собственников дворянского сословия уменьшилось на $20 \%$, их землевладения - на $32 \%$, а средний размер землевладений - на $15 \%$. У других сословий в структуре землевладений прослеживались противоположенные тенденции - количество земельных собственников увеличивалось. У крестьян и мещан также выросли средние размеры землевладений в 1,5 и 1,7 раза соответственно, но у купцов они сократились в 1,3 раза.

Средние размеры частных землевладений дают только общую картину перераспределения частновладельческих земель между сословиями.

При рассмотрении отдельных губерний района распределение частновладельческих земель между сословиями выглядит иначе.

Рассмотрим пример Курской губернии, которая из всех губерний района отличалась наибольшим количеством мелких земельных собственников. В 1877 году 24012 личным землевладельцам губернии принадлежало 1416 тыс. дес. В среднем на одного владельца дворянского сословия приходилось 204 дес., купеческого - 214 дес., мещанского 15 дес. и крестьянского - 8 дес. [Статистика землевладения..., 1907, с. 16-17]. К 1905 году тенденции в перераспределении личной земельной собственности в губернии соответствовали тенденциям, имевшимся во всем Центральном Черноземье.

Таблица 2

Table 2

Структура частного землевладения Курской губернии в 1877 и 1905 годах [Статистика землевладения..., 1907, с. 12-17]. Private landownership formation in the Kursk region in 1877 and 1905

\begin{tabular}{|c|c|c|c|c|c|c|c|c|c|c|}
\hline \multirow[b]{2}{*}{ 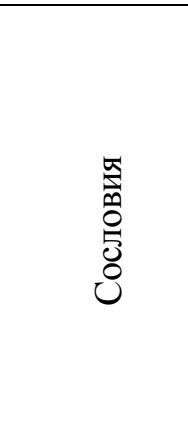 } & \multicolumn{5}{|c|}{1877 год } & \multicolumn{5}{|c|}{1905 год } \\
\hline & 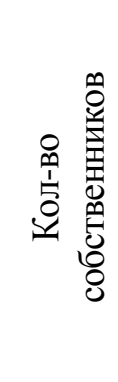 & 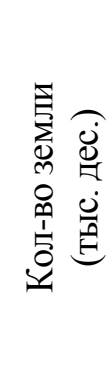 & 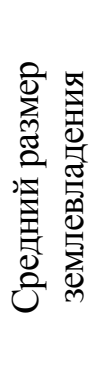 & 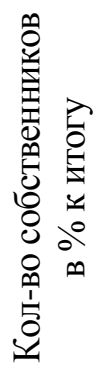 & 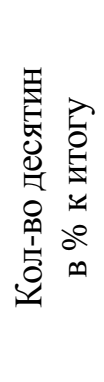 & 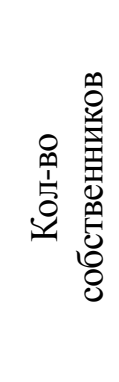 & 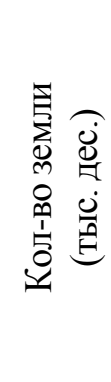 & 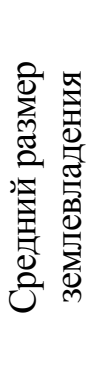 & 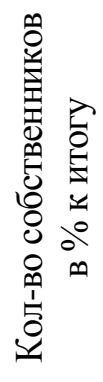 & 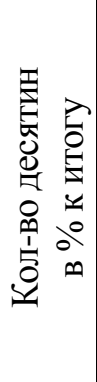 \\
\hline Дворяне & 5712 & 1165 & 204 & 23,5 & 82 & 4533 & 859 & 190 & 15 & 68 \\
\hline Купцы & 415 & 89 & 214 & 2 & 6 & 753 & 97 & 129 & 3 & 8 \\
\hline Мещане & 1189 & 17 & 15 & 5 & 1 & 1092 & 35 & 32 & 4 & 3 \\
\hline Крестьяне & 16222 & 136 & 8 & 67,5 & 10 & 22973 & 258 & 11 & 77 & 20 \\
\hline Остальные & 474 & 9 & 18 & 2 & 1 & 428 & 11 & 25 & 1 & 1 \\
\hline Итого & 24012 & 1416 & - & 100 & 100 & 29779 & 1260 & - & 100 & 100 \\
\hline
\end{tabular}

В сравнении со средними значениями большинство землевладельцев губернии были мелкими земельными собственниками. В 1877 году 61,5\% личных землевладельцев губернии имели в собственности менее 10 дес. и $29 \%$ - от 10 до 100 дес. Количество землевладельцев, имеющих в собственности более 1000 дес., было чуть более $2 \%$ [Статистический временник..., 1886. С. 32-33]. К 1905 году количество землевладельцев, владевших до 10 дес., выросло до 65 \%, от 10 до 100 дес. - сократилось всего на 0,5\%, а свыше 1000 дес. - до 1,5 \% [Статистика землевладения..., 1907, с. 71].

Крупными землевладельцами губернии были в основном представители дворянского сословия. Отдельные дворянские землевладения превышали 20 тыс. дес. Так, в Пу- 
тивльском уезде кн. А.В. Барятинскому принадлежало 20219 дес. ${ }^{33}$ В Грайвороновском уезде владения кн. Н.Б. Юсупова составляли 21463 дес. ${ }^{34}$

Вместе с тем в 1877 году $16 \%$ дворян губернии имели в собственности не более 10 дес., $49 \%$ - от 10 дес. до 100 дес., $26 \%$ - от 100 до 500 дес., $3 \%$ - от 500 дес. до 1000 дес. [Статистический временник ..., 1886, с. 34]. К 1905 году их количество составило $24 \%, 45 \%, 23$ \% и $2 \%$ соответственно [Статистика землевладения..., 1907, с. 71].

Из представленных данных видно, что количество дворян-землевладельцев, имевших в собственности до 10 дес., увеличилось, а от 10 дес. до 1000 дес. - сократилось. В 1877 и 1905 годах доля дворян, владевших свыше 5000 дес., составляла менее 1 \% [Статистический временник..., 1886, с. 35; Статистика землевладения..., 1907, с. 71].

Наряду с дворянами среди относительно крупных землевладельцев губернии встречались представители других сословий. В Щигровском уезде купцу Александру Федоровичу Антимонову принадлежало 2703 дес. ${ }^{35}$ земли. Самым крупным землевладельцем крестьянского сословия был Сурин Филипп Степанович, в Дмитриевском уезде ему принадлежало 650 дес. $^{36}$

Таким образом, тенденции, происходившие не земельном рынке Центральночерноземного района, в целом соответствовали общероссийским тенденциям. Товарооборот дворянских землевладений района был немного больше, чем в среднем по Европейской России. С 1863 по 1905 годы дворяне были основными участниками земельного рынка. Вместе с тем дворянские землевладения постепенно переходили от дворян к другим сословиям, главным образом к купцам, крестьянам и мещанам. Купцы были на втором месте после дворян по площади землевладений и по средним размерам земельных участков. Большинство личных землевладельцев были крестьянами. Средние размеры их землевладений были намного меньше, чем у дворян и купцов. Несмотря на то, что развитие земельного рынка с 1863 по 1905 годы оказывало существенное влияние на межсословное перераспределение частной земельной собственности, к 1905 году большинство частновладельческих земель продолжало принадлежать дворянам. В 1877 году большинство дворян были мелкими земельными собственниками. К 1905 году тенденция к сокращению средних размеров дворянских землевладений усилилась.

\section{Список литературы}

1. Анфимов. А.М. 1969. Крупное помещичье хозяйство европейской России (Конец XIX - начало XX в.). АН СССР. Ин-т истории СССР. М., Наука, 394. СПб., 1871.

2. Военно-статистический сборник. Вып. IV. Под ред. генерал-Майора Н.Н. Обручева.

3. Ковальченко И.Д., Милов Л.В. 1974. Всероссийский аграрный рынок, XVIII - начало XX в. Опыт количественного анализа. М., Наука, 399.

304.

4. Корелин А.П. 1879. Дворянство в пореформенной России 1861-1904 гг. М., Наука,

5. Князь Васильчиков А. 1876. Землевладение и земледелие в России и других Европейских государствах: в 2-х т. СПб., типография Стасюлевича. Т. II. 787.

6. Литвак Б.Г. 1991. Русская деревня в реформе 1861 г. Черноземный центр. 1861-1895 гг. М., Издательство политической литературы, 93.

7. Литуев В.Н. 1997. Земельная собственность как дворянская монополия в капиталистической России. М., Калита, 148.

8. Лященко П.И. 1901. Очерки аграрной эволюции. СПб., б. м., 446.

\footnotetext{
${ }^{33}$ Государственный архив Курской области (далее ГАКО). Ф. 4. Оп. 1. Д. 91. Л.3-28.

${ }^{34}$ ГАКО. Ф. 4. ОП. 1. Д. 84. Л. 4-5.

${ }^{35}$ ГАКО. Ф. 4. ОП. 1. Д. 97. Л. 32.

${ }^{36}$ ГАКО. Ф. 4. Оп. 1. Д. 85. Л. 24.
} 
9. Материалы по статистике движения землевладения в России. Вып. IV: Свод данных о купле-продаже земель в 45 губерниях Европейской России за тридцатилетие с 1863 по 1892 гг. Под ред. А.Е. Рейнбота. СПб., Тип. Киршбаума, 1901.

10. Материалы по статистике движения землевладения в России. Вып. XIII.: Погубернские итоги мобилизации земель и средние земельные цены за 40-летие. 1863-1902 гг. Под ред. А.Е. Рейнбота. СПб., Тип. Киршбаума, 1907.

11. Михалевич В. 1862. Материалы географии и статистики России. Воронежская губерния. Собранные офицерами генерального штаба. СПб., Издательство библиотеки графа Панина, 187.

12. Островский А.В. 2013. Зерновое производство Европейской России в конце XIX начале XX в. СПб., 418.

13. Проскурякова Н.А. 1973. Размещение и структура дворянского землевладения Европейской России в конце XIX - начале XX вв. История СССР. 1: 55-75.

14. Святловский В.В. 1911. Мобилизация земельной собственности в России (1861-1908 гг.). СПб., Книгоиздательство «Начало», 116.

15. Скребицкий А. 1865. Крестьянское дело в царствование императора Александра II. Бонн-на-Рейне, Т. II. Ч. II. 1624.

16. Статистика землевладения 1905 г. Свод данных по 50 губерниям Европейской России. СПб., ЦСК МВД, 1907.

17. Статистика поземельной собственности и населенных мест Европейской России. Вып. І. СПб., 1880.

18. Статистика землевладения. Воронежская губерния. Вып. V. СПб., ЦСК МВД, 1905.

19. Статистика землевладения. Курская губерния. Вып. XXXVII. СПб., ЦСК МВД,1906.

20. Статистический временник Российской империи. Серия ІІІ. Вып. 10. СПб., ЦСК МВД, 1886.

21. Фортунатов А.Ф. 1893. Сельскохозяйственная статистика Европейской России. М., Типолитография т-ва И.Н. Кушнерев, 246.

22. Цифровые данные о поземельной собственности в Европейской России. СПб., 1897.

\section{References}

1. Anfimov A.M. 1969. Krupnoe pomeshhich'e hozjajstvo evropejskoj Rossii (Konec XIX nachalo XX v.) [Large-scale estates of European Russia (the late 19th century - early 20th)]. AN SSSR. In-t istorii SSSR. M., Nauka, 394.

2. Voenno-statisticheskij sbornik. Vyp. IV [Military Statistics, ed. 4]. Pod red. general-Majora N.N. Obrucheva. SPb., 1871.

3. Koval'chenko I.D., Milov L.V. 1974. Vserossijskij agrarnyj rynok, XVIII - nachalo XX v. Opyt kolichestvennogo analiza [All-Russian agrarian market, 18 - early 20th century. Quantitative analysis attempt]. M., Nauka, 399.

4. Korelin A.P. 1879. Dvorjanstvo v poreformennoj Rossii 1861-1904 gg. [Landed gentry in post-reform Russia (1861-1904)] M., Nauka, 304.

5. Knjaz' Vasil'chikov A. 1876. Zemlevladenie i zemledelie v Rossii drugih Evropejskih gosudarstvah: v 2-h t. [Land tenure and farming in Russia and other European countries: in two volumes]. $\mathrm{SPb}$., tipografija Stasjulevicha T. II. 787.

6. Litvak B.G. 1991. Russkaja derevnja v reforme $1861 \mathrm{~g}$. Chernozemnyj centr. 1861-1895 gg. [Russian village after the reform of 1861 Central Chernozem region] M., Izdatel'stvo politicheskoj literatury, 93.

7. Lituev V.N. 1997. Zemel'naja sobstvennost' kak dvorjanskaja monopolija v kapitalisticheskoj Rossii [Monopolized land ownership by the nobility in capitalist Russia] M., Kalita, 148. b. m., 446 .

8. Ljashhenko P.I. 1901. Ocherki agrarnoj jevoljucii [Essays on the agrarian revolution]. SPb.,

9. Materialy po statistike dvizhenija zemlevladenija v Rossii. Vyp. IV: Svod dannyh o kupleprodazhe zemel' v 45 gubernijah Evropejskoj Rossii za tridcatiletie s 1863 po 1892 gg. [Statistics on Russian agricultural progress, ed. 4. Set of data related to the land mobility in 45 provinces of European Russia during the period from 1863 to 1892]. Pod red. A.E. Rejnbota. SPb., Tip. Kirshbauma, 1901. 
10. Materialy po statistike dvizhenija zemlevladenija v Rossii. Vyp. XIII.: Pogubernskie itogi mobilizacii zemel' i srednie zemel'nye ceny za 40-letie. 1863-1902 gg. [Statistics on Russian agricultural progress, ed. 13. Results of land mobility in each province and average land prices during the period from 1863 to 1902]. Pod red. A.E. Rejnbota. SPb., Tip. Kirshbauma, 1907.

11. Mihalevich V. 1862. Materialy geografii i statistiki Rossii. Voronezhskaja gubernija. Sobrannye oficerami general'nogo shtaba [Russian geography and statistics. The province of Voronezh. Data collected by by General Staff officers]. SPb., Izdatel'stvo biblioteki grafa Panina, 187.

12. Ostrovskij A.V. 2013. Zernovoe proizvodstvo Evropejskoj Rossii v konce XIX - nachale $\mathrm{XX}$ v. [Crop production of the European Russia in the late 19th century - early 20th century]. SPb., 418 .

13. Proskurjakova N.A. 1973. Razmeshhenie i struktura dvorjanskogo zemlevladenija Evropejskoj Rossii v konce XIX - nachale XX vv. [Placement and formation of noble land ownership in European the late 19th century - early 20th]. Istorija SSSR. 1: 55-75.

14. Svjatlovskij V.V. 1911. Mobilizacija zemel'noj sobstvennosti v Rossii (1861-1908 gg.). [Land mobility in Russia (1861-1908)]. SPb., Knigoizdatel'stvo «Nachalo», 116.

15. Skrebickij A. 1865. Krest'janskoe delo v carstvovanie imperatora Aleksandra II [Peasant cause during the reign of Alexander II. Bonn on the Rhine, vol. II. Part II. 1624] Bonn-na-Rejne, T. II. Ch. II. 1624.

16. Statistika zemlevladenija 1905 g. Svod dannyh po 50 gubernijam Evropejskoj Rossii. [Land mobility statistics (1905). Set of data on 50 provinces of European Russia] SPb., CSK MVD, 1907.

17. Statistika pozemel'noj sobstvennosti i naselennyh mest Evropejskoj Rossii. Vyp. I. [Statistics of land ownership and localities of European Russia. Ed. 1]. SPb., 1880.

18. Statistika zemlevladenija. Voronezhskaja gubernija [Land ownership statistics. Voronezh Region]. Vyp. V. SPb., CSK MVD, 1905.

19. Statistika zemlevladenija. Kurskaja gubernija [Land ownership statistics. Kursk Region]. Vyp. XXXVII. SPb., CSK MVD, 1906.

20. Statisticheskij vremennik Rossijskoj imperii. Seriya III. Vyp. 10 [Annals of Statistika's of russian empire] SPb., CSK MVD, 1886.

21. Fortunatov A.F. 1893. Sel'skohozjajstvennaja statistika Evropejskoj Rossii [Agricultural statistics of European Russia]. M., Tipolitografija t-va I.N. Kushnerev, 246.

22. Cifrovye dannye o pozemel'noj sobstvennosti v Evropejskoj Rossii [Figures for the land ownership in European Russia]. SPb., 1897.

\section{ИНФОРМАЦИЯ ОБ АВТОРАХ}

Громова Виктория Валентиновна, аспирант кафедры российской истории и документоведения Белгородского государственного национального исследовательского университета, г. Белгород, Россия

Тонких Владимир Алексеевич, доктор исторических наук, профессор кафедры международных отношений и мировой политики Воронежского государственного университета, г. Воронеж, Россия

\section{INFORMATION ABOUT ATHORS}

Viktoriya V. Gromova, postgraduate student of the Department of Russian history and pre-study Belgorod State National Research University, Belgorod, Russia

Vladimir A. Tonkih, Doctor of Historical Sciences, Professor of the Department of International Relations and World Politics, Voronezh State University, Voronezh, Russia 